\author{
Ks. Janusz Królikowski* \\ UPJPII w Krakowie Wydziat Teologiczny Sekcja w Tarnowie
}

\title{
NOWOŻYTNE PRZEMIANY W TEOLOGII STWORZENIA
}

\author{
„Wierzymy w Jednego Boga, Ojca, Syna i Ducha \\ Świętego, Stwórcę rzeczy widzialnych - do jakich \\ należy ten świat, w którym przebiega nasze krót- \\ kie życie..."
}

(Paweł $\mathrm{VI}^{1}$ )

Zasługuje na niewątpliwą uwagę fakt, że prawda wiary dotycząca stworzenia świata stanowi jedną $\mathrm{z}$ najbardziej pierwotnych prawd, którą sformułowało chrześcijaństwo, szukając swojej tożsamości i swojej specyfiki w świecie starożytnym. Już Adolf von Harnack zauważył, że gdy chrześcijaństwo wchodziło w świat starożytny, weszło $\mathrm{w}$ niego właściwie $\mathrm{z}$ dwoma podstawowymi prawdami: z prawdą, że Jezus z Nazaretu jest wiecznym Słowem Boga - Synem Bożym, i prawdą, że Bóg jest Stwórcą, czyli że w Nim wszystko ma początek. Co więcej, Harnack ideę stworzenia uznawał za „znamienite zwycięstwo" chrześcijaństwa, ponieważ dzięki niej Bóg chrześcijan został ukazany jako jedyna siła działająca $w$ świecie $^{2}$. Prawda o stworzeniu, nawet jeśli nie była od początku jasno sformułowana i w kolejnych wiekach stale pogłębiano jej rozumienie, dokonała przewrotu w spojrzeniu na świat i człowieka, służąc przede wszystkim eliminowaniu wszelkich tendencji zmierzających do ubóstwienia kosmosu lub jego elementów oraz dokonując właściwego usytuowania egzystencjalnego człowieka $\mathrm{w}$ relacji do świata. $Z$ biegiem czasu, biorąc pod uwagę podstawowe znaczenie problematyki dotyczącej poznania i rozumienia świata dla całości wiary chrześcijańskiej i widząc coraz jaśniej wielo-

* Ks. Janusz Królikowski, dr hab. teologii, prof. UPJPII w Krakowie, kierownik katedry teologii dogmatycznej na Wydziale Teologicznym Sekcja w Tarnowie UPJPII w Krakowie, wykładowca w Papieskim Uniwersytecie Świętego Krzyża w Rzymie, wiceprzewodniczący Polskiego Towarzystwa Mariologicznego, członek zwyczajny Papieskiej Międzynarodowej Akademii Maryjnej w Rzymie.

${ }^{1}$ Paweł VI, Wyznanie wiary Ludu Bożego, tłum. J. Królikowski, Kraków 2013, s. 15.

2 Por. A. von Harnack, Das Wesen des Christentums. Sechzehn Vorlesungen vor Studierenden aller Facultäten im Wintersemester 1899-1900 an der Universität Berlin, Leipzig 1901, s. 143. 
aspektowe znaczenie teologii stworzenia, św. Tomasz z Akwinu mógł sformułować przekonanie, rzadko dzisiaj zresztą przywoływane, że każdy błąd w odniesieniu do świata, który rodzi się między innymi z niezrozumienia problematyki dotyczącej stworzenia, staje się zarazem źródłem błędu w odniesieniu do człowieka i w odniesieniu do Boga ${ }^{3}$. Te bardzo podstawowe fakty wskazują, że kwestia stworzenia ma kluczowe znaczenie w doświadczeniu chrześcijańskim.

W tym miejscu nie będziemy analizować długiego rozwoju historycznego teologii stworzenia (protologii) i podstawowych dogmatów, które wyznaczają jej ramy interpretacyjne w doktrynie katolickiej. Zwrócimy natomiast uwagę przede wszystkim na kontekst filozoficzno-teologiczny, który w dwóch ostatnich stuleciach wpłynął na świadomość dotyczącą znaczenia prawdy wiary mówiącej o Bogu jako Stwórcy i Jego stworzeniu - dokonując jej pomniejszenia, a następnie na będące konsekwencją zmian w świadomości konkretne, nie zawsze trafne, ujmowanie tej prawdy w systematycznej refleksji teologicznej - mające potem dalsze negatywne reperkusje w jej przekazywaniu w ramach katechezy i przepowiadania w Kościele.

\section{PRZEMIANY FILOZOFICZNO-KULTUROWE I ICH ODZWIERCIEDLENIE W TEOLOGII STWORZENIA}

1. Najbardziej znaczący wpływ na teologię stworzenia wywarła filozofia XIX i pierwszej połowy XX wieku. Poszczególne jej kierunki, choć wzajemnie nie powiązane ze sobą, prowadziły do pojawiania się przeciwstawnych tendencji i nacisków, które w różny sposób oddziaływały na wiarę chrześcijańską jako całość i na poszczególne prawdy, które kształtują jej tożsamość ${ }^{4}$.

$\mathrm{Na}$ początku XIX wieku rozpowszechniony idealizm oświeceniowy wzbudził generalną nieufność względem tego, co materialne i zewnętrzne w stosunku do człowieka. Filozofia czystego ducha zostawiła na boku zainteresowanie kosmosem, sprowadzając wszystko do sfery intelektualnej i duchowej. Pociągnęło to za sobą rezygnację z zainteresowania teologią stworzenia, która, będąc w tradycyjnym ujęciu jednostronnie zainteresowana stworzeniem w aspekcie kosmicznym, utraciła w znacznym stopniu swoje samouzasadnienie. W takim ujęciu, przynajmniej na pierwszy rzut oka, teologia niewiele wnosi do rozumienia sfery duchowej, czyli duszy, rozumu, wolności itd., dlatego też zrezygnowano z zainteresowania taką teologią.

2. Karol Marks wprawdzie zainteresował się światem materialnym, dokonując jego redukcji materialistycznej, ale bardzo ostro wypowiedział się przeciw zajmowaniu się kwestią pochodzenia i początku świata. Świat stanowił dla

\footnotetext{
${ }^{3}$ Por. Tomasz z Akwinu, Summa contra gentiles II, 3: Error circa creaturas redundant in falsam de Deo sententiam.

${ }^{4}$ Por. R. Buttiglione, A. Scola, Rozważania o problematyce stworzenia $w$ myśli wspótczesnej. Podstawowe treści chrześcijańskiego dogmatu o stworzeniu, „Communio” 2(1982), nr 4, s. 67-85.
} 
niego tylko pewną daną faktyczną, którą trzeba sobie uświadomić, by podjąć zadanie jej przekształcania, w którym to zdaniu wyraża się człowiek i osiąga swoje wypełnienie. Słynne jest stwierdzenie Marksa, według którego pytanie o początek i pochodzenie świata można włożyć między bajki. Niejednokrotnie powoływano się na to stwierdzenie w poszukiwaniach filozoficznych, nie pozostających także bez wpływu na podejmowaną refleksję teologiczną ${ }^{5}$.

Efektem rozpowszechnionego monizmu materialistycznego stało się pozbawienie materii jej wymiaru „symbolicznego”. Nie jest ona już traktowana, jak w tradycyjnych ujęciach filozoficzno-teologicznych, jako „głos Boży” (vox Dei), czy też „księga”, która zawiera zapisane w sobie przesłanie skierowane przez Boga do człowieka (liber naturae), stanowiące ważny etap objawienia Bożego. Materia jest już tylko tworzywem danym człowiekowi do dyspozycji, aby nim dowolnie rozporządzał w swojej pracy. W związku z tym stało się obce tej mentalności na przykład takie stwierdzenie Martina Bubera: „Bóg zwraca się bezpośrednio do człowieka za pośrednictwem rzeczy i istot, które wkłada w jego życie; człowiek odpowiada w taki sposób, w jaki odnosi się do rzeczy i istot posłanych przez Boga"6.

Marksizm - i jego rozmaite pochodne - ze swoim redukcjonizmem materialistycznym wywarły bardzo znaczny wpływ na rozumienie techniki i technologii, które zostały dane człowiekowi do arbitralnego dysponowania, tracąc wszelkie odniesienie do etyki, duchowości i mądrości, a tym samym tworząc nową, odhumanizowaną wizję świata, która dzisiaj jest bardzo popularna.

3. Filozofie egzystencjalistyczne, mimo iż starają się uchwycić i opisać egzystencję człowieka w świecie, również nie okazały się sprzyjające i inspirujące dla teologii stworzenia. Zajęly się one wprawdzie człowiekiem i jego władzami duchowymi, starając się z determinacją określić sens jego istnienia i jego przeznaczenie, ale - można ogólnie powiedzieć - zajęły się samym człowiekiem, w nim tylko szukając odpowiedzi na stawiane pytania, lekceważąc odniesienie człowieka do świata. Ponieważ - jak zostało już zaznaczone tradycyjna teologia stworzenia była ukierunkowana przede wszystkim kosmologicznie, mało zajmując się człowiekiem i znaczeniem antropologicznym prawdy o stworzeniu, jej inspirująca siła na ogół nie została uwzględniona w poszukiwaniach filozoficznych.

W ramach rozmaitych kierunków egzystencjalizmu bardzo ważne, a niekiedy wręcz pierwsze miejsce, zajęła kwestia zła. Tradycyjna teologia zawsze ujmowała ten problem $\mathrm{w}$ kontekście protologii i nie ulega wątpliwości, że jest to ujęcie o zasadniczym znaczeniu dla jego spójnego przedstawienia (nie mówimy o rozwiązaniu). Choć w ramach takiego ujęcia na pewno nie można znaleźć odpowiedzi na wszystkie pytania, które rodzą się w człowieku pod wpływem obecności zła w świecie, to jednak wyznacza ono inspirującą i ukierunkowującą perspektywę dla prowadzonych poszukiwań, przede wszystkim

${ }^{5}$ Por. S. Kowalczyk, Chrześcijańska a marksistowska myśl o stworzeniu, „Communio" 2(1982), nr 4, s. 86-102.

${ }^{6}$ M. Buber, Le message hassidique, „Dieu Vivant” 2(1945), s. 18. 
dlatego, że wychodzi w swoich poszukiwaniach od kwestii Boga. Św. Augustyn jest klasykiem takiego ujęcia, które streszcza postawione na początku pytanie: „Jeśli jest Bóg, to skąd zło?”. Kryterium hermeneutycznym prowadzonych refleksji jest więc kwestia Boga, w świetle której dąży się do zrozumienia zła, starając się potem wyjaśnić jego obecność w dziejach człowieka i świata, także w wymiarze zbawczym. Jest to ujęcie mające swoje źródła w tradycji biblijnej, która podejmując tę kwestię, zawsze ma na względzie potrzebę usytuowania problemu zła na pierwotnym fundamencie religijnym, jawiącym się jako jedyny możliwy do adekwatnego szukania odpowiedzi. Do takiego wniosku prowadzi przede wszystkim Księga Hioba, której genialność ukazuje się nawet przy bardzo pobieżnej lekturze. Oczywiście, ta genialność nie polega na zaproponowanych rozwiązaniach, ale na właściwym postawieniu problemu zła, które pozostaje ponadczasowe.

W różnych nurtach egzystencjalizmu charakteryzujących się antropologicznym punktem wyjścia, tradycyjne pytanie o zło uległo przeformułowaniu, W związku z czym jest stawiane przede wszystkim w następującej postaci: „Jeśli jest zło, to czy jest Bóg?” - a więc odwrotnie niż zaproponował to na przykład św. Augustyn. Trzeba powiedzieć, że w takiej perspektywie stajemy wobec bardzo poważnych trudności interpretacyjnych, które najczęściej kończą się przyjęciem ateistycznych rozwiązań. Stały się one obecnie bardzo popularne w ramach tak zwanego nowego ateizmu, który nie jest niczym innym, jak ujmowaniem wszelkich problemów religijnych w perspektywie przyjętej w ramach filozofii egzystencjalistycznych o charakterze ateistycznym ${ }^{7}$.

4. Niepokojący wpływ na teologię stworzenia wywarł rozwój nauk przyrodniczych, szczególnie kosmologii i biologii (w XIX wieku bardzo wpływową nauką była geologia), a zwłaszcza wyrosła w ich ramach teoria ewolucji. Efektem pochopnych wniosków i nieadekwatnych - czemu zresztą trudno się dziwić - ujęć zagadnienia jest bardzo rozpowszechnione dzisiaj przeciwstawianie stworzenia i ewolucji. Takie ujęcie wyrasta przede wszystkim z kręgów fundamentalistycznego interpretowania Biblii, popularnego w niektórych wpływowych kręgach protestanckich. Ma to miejsce głównie w Stanach Zjednoczonych, ale zasięg oddziaływania formułowanych tam ujęć jest bardzo szeroki ${ }^{8}$. Główny błąd tego ujęcia wynika ze sprowadzenia doktryny o stworzeniu do kwestii „wyprodukowania rzeczy” (productio rerum), które istnieją w kosmosie. Doktryna stworzenia obejmuje wiele innych, dużo ważniejszych elementów, ponieważ sama productio rerum jest elementem $\mathrm{w}$ znacznym stopniu pomocniczym w ramach tej prawdy. Zapomina się, że pierwszorzędnie doktryna stworzenia podkreśla, iż świat nie jest boski oraz że łączy go „jakaś relacja” z Bogiem". Owszem, kwestia konkretnego powstania świata i jego elementów, budzących od starożytności niekwestionowany podziw

\footnotetext{
${ }^{7}$ Por. J.F. Haught, God and New Atheism. A Critical Response to Dawkins, Harris, and Hitchens, Louisville 2008.

${ }^{8}$ Por. D. Lecourt, L'Amerique entre la Bible et Darwin, Paris 1992.

${ }^{9}$ Por. Tomasz z Akwinu, Summa contra gentiles, II, 18.
} 
człowieka, jest jakoś wpisana w całość teologii stworzenia, ale pozostaje otwarta na wiele interpretacji, które pojawiają się już obficie u ojców Kościoła ${ }^{10}$.

Współcześnie bardzo duże reperkusje w dziedzinie antropologii wywierają nauki przyrodnicze, które - wychodząc przede wszystkim z założeń ideologicznych - pozbawiają człowieka jego odrębności i specyfiki w świecie. Ulega pomniejszeniu wyższość człowieka nad całym światem natury. Jest to spowodowane wpływami materialistycznymi oraz ewolucjonistycznymi, które $\mathrm{z}$ ewolucji w świecie przyrody uczyniły kategorię filozoficzną, a obecnie za jej pomocą starają się interpretować to, co ludzkie. W takich interpretacjach człowiek najczęściej traci swoje specyficzne, transcendentne przymioty, takie jak osobowość, tożsamość, wolność, godność itd. Otwiera to drogę do czynienia z człowieka tylko jednej z wielu istot żyjących w świecie, a następnie do sprowadzenia go do przedmiotu, którym można dowolnie dysponować. $\mathrm{W}$ takich ujęciach ulega potem pomniejszeniu, a nawet wyeliminowaniu wymiar etyczny i kulturowy ludzkiej egzystencji ${ }^{11}$.

5. Na kwestię teologii stworzenia miały pewien wpływ badania egzegetyczne, które przyczyniły się do jej pomniejszenia. Postawiły one bardzo ważne, do dzisiaj jeszcze nierozstrzygnięte jednoznacznie, pytanie o miejsce stworzenia $w$ ramach wiary biblijnej. U początków dyskusji na ten temat stoi artykuł Gerharda von Rada z 1936 roku, w którym autor zwraca uwagę, iż w zakresie teologii biblijnej, w której pierwszorzędne miejsce zajmuje przymierze, kwestia stworzenia jawi się jako element tylko poniekąd pomocniczy. Owszem, stworzenie jest stałym elementem tradycji biblijnej, stanowi w pewnym sensie „scenę”, na której rozgrywa się działanie Boga i urzeczywistnia się prowadzenie człowieka do zbawienia, ale funkcja soteriologiczna stworzenia jest obecna w Stary Testamencie tylko w bardzo ograniczonym stopniu ${ }^{12}$. W Nowym Testamencie kwestia stworzenia również nie odgrywa jakiejś własnej i specyficznej roli.

Podjęte badania biblijne, skoncentrowane na analizie poszczególnych tekstów biblijnych dotyczących stworzenia, doprowadziły do ważnego wnio$\mathrm{sku}$, a mianowicie postulują one potrzebę traktowania stworzenia i zbawienia jako jednej, organicznej rzeczywistości. Mimo iż temat stworzenia jest kwestią poniekąd dopełniającą $\mathrm{w}$ odniesieniu do wiary biblijnej, to jednak jest on niezastąpiony $\mathrm{w}$ dojściu do religijnego rozumienia człowieka, jego działania i jego przeznaczenia. Niestety, na obecnym etapie refleksji teologicznej jest to

\footnotetext{
${ }^{10}$ Por. Y. Congar, Le theme du Dieu créateur et les explications de l'Hexameron dans la tradition chrétienne, w: L'homme devant Dieu. Mélanges offerts au P. Henri de Lubac, t. 1, Paris 1964, s. 189-222.

${ }^{11}$ Ważną krytykę wskazanego ujęcia można znaleźć w: Ch. Delsol, Czym jest człowiek? Kurs antropologii dla niewtajemniczonych, tłum. M. Kowalska, Kraków 2011.

${ }^{12}$ Por. G. von Rad, Das theologische problem des alttentestamenlichen Schöpfungsglaubens, w: Werden und Wessen des Alten Testaments. Vorträge gehalten auf der internationalen Tagung Alttestamentlicher Forscher zu Göttingen vom 4-10 September 1935, red. P. Volz, F. Stummer, J. Hempel, Berlin 1936, s. 138-147 (przedruk: tenże, Gesammelte Studien zum Alten Testament, Munich 1958, s. 136-147).
} 
tylko postulat, który wciąż czeka na adekwatne dostrzeżenie i rozwinięcie w ramach teologii systematycznej. Obecnie proponowane wykłady teologii stworzenia nie uwzględniają kluczowego znaczenia tego postulatu ${ }^{13}$.

6. Trzeba wreszcie powiedzieć, że także teologia dogmatyczna, trzymając się utrwalonych schematów, zwłaszcza w nurcie neoscholastycznym, nie stanęła na wysokości zadania w reagowaniu na nowe pytania stawiane odnośnie do stworzenia, które pojawily się w ostatnich dwóch wiekach. Pozostawała ona, i zresztą wciąż pozostaje, ukierunkowana kosmologicznie, pomijając tym samym wiele kluczowych kwestii, które są ważne przede wszystkim dla kształtowania odpowiedniego rozumienia człowieka oraz jego relacji do świata i Boga. Mało więc uwagi w teologii stworzenia poświęcono kwestii człowieka i jego specyfiki w odniesieniu do całego pozostałego stworzenia. Nie uwzględniano, z małymi wyjątkami, kwestii stworzenia człowieka jako mężczyzny i kobiety. Nie postawiono wyraźnie pytania o to, co wyraża z antropologicznego i teologicznego punktu widzenia dwoistość płciowa wpisana $\mathrm{w}$ naturę istot żywych, a przede wszystkim w naturę człowieka. U podstaw wielu ideologicznych ujęć, które dzisiaj się pojawiają, na przykład destrukcyjna ideologia gender, znajduje się także fakt, iż antropologia i teologia w niewielkim zakresie zajęły się tymi zagadnieniami, poświęcając im tylko ogólne uwagi w ramach teologii małżeństwa, a tym samym pomijając głęboko naturalne, a następnie także religijne, znaczenie płciowości w życiu człowieka.

Nie nadążono w teologii za kwestią zmieniającej się relacji człowieka do świata, zwłaszcza do świata tworzonego i przetwarzanego przez niego $\mathrm{w}$ ramach nauki, techniki i technologii. Zapomniano o bardziej pogłębionym ukazywaniu celu stworzenia wszechświata i człowieka - tego, co za Einsteinem można nazwać ,zamiarem Boga” (Mind of God) w stosunku do świata. Nie zwrócono uwagi na kwestie racjonalności świata oraz wolności człowieka jako kluczowe aspekty teologii stworzenia.

Patrząc globalnie, trzeba powiedzieć, że jednym z bardzo zasadniczych defektów tradycyjnej, zwłaszcza neoscholastycznej, teologii stworzenia jest brak ukazania jej związków z innymi traktatami teologicznymi. Nie zastosowano $\mathrm{w}$ jej ramach zasadniczego pryncypium teologicznego, którym jest powiązanie tajemnic między sobą (nexus mysteriorum). Protologia została $\mathrm{w}$ ten sposób pozbawiona realnego znaczenia dla całości teologii, a co się z tym wiąże, także dla wiary Kościoła i poszczególnych wierzących.

\section{PROPOZYCJE I PERSPEKTYWY}

W kontekście pokazanych schematycznie wyzwań, można po prostu powiedzieć, że autentyczna i aktualna teologia stworzenia powinna zdać sobie sprawę z tych wszystkich problemów filozoficzno-teologicznych i z istniejących w jej ramach braków. Sprawiają one, że teologia pojęta jako całość traci

${ }^{13}$ Por. H. Bourgeois, L'affirmation de la creation dans l'expérience chrétienne, „Recherches de Science Religieus” 84(1996), s. 497-517. 
kontakt ze światem, w którym Kościół pełni swoją misję i w której żyją wierzący. Teologia stworzenia jest newralgicznym obszarem relacji wiary i świata, mającej swój punkt wyjścia i zarazem punkt odniesienia w Jezusie Chrystusie. Można więc powiedzieć, że od tego, w jaki sposób ujmie się to zagadnienie, zależy potem kształt, jaki przyjmie cała teologia - w jaki sposób będzie ujmować relację człowieka z całą otaczającą go rzeczywistością, a zwłaszcza jak zostanie ustawiony problem chrystologiczny. Miał rację kard. Joseph Ratzinger, gdy $\mathrm{w}$ jednej $\mathrm{z}$ konferencji stwierdził: „Sprowadzenie na margines doktryny o stworzeniu redukuje pojęcie Boga, a w konsekwencji chrystologię. Zjawisko religijne nie znajduje $\mathrm{w}$ tym wypadku już wyjaśnienia poza przestrzenią psychologiczną i socjologiczną; świat materialny jest ograniczony polem fizyki i techniki. Tylko jeśli [...] byt, łącznie z materią, jest rozpatrywany jako wychodzący z rąk Stwórcy i podtrzymywany w Jego rękach, wtedy Bóg jest także rzeczywiście naszym Zbawicielem i naszym życiem, prawdziwym życiem" 14 .

W tym miejscu nie formułujemy jakiejś całościowej propozycji dotyczącej struktury traktatu o stworzeniu, ale zamierzamy tylko wskazać niektóre zagadnienia, których opracowanie mogłoby bardziej bezpośrednio przyczynić się do zaktualizowania refleksji teologicznej nad stworzeniem. $Z$ tego też powodu muszą tutaj ogólnie powrócić niektóre uwagi, które już wyżej zostały sformułowane.

1. Trzeba więc na pierwszym miejscu jeszcze raz $z$ determinacją powrócić do pytania o miejsce wiary w stworzenie najpierw w ramach wiary Abrahama, a potem także w ramach wiary Kościoła. Jest niewątpliwie ważną sprawą to, że w ramach Starego Testamentu kwestia powołania Abrahama i jego odpowiedź wiary wyprzedza chronologicznie biblijne opisy stworzenia, które obecnie znajdują się na początku Księgi Rodzaju. Właściwe skodyfikowanie biblijnej teologii stworzenia nastąpiło w czasie niewoli babilońskiej, a więc w okresie, który postawił wierze starotestamentalnej, naznaczonej poważnym kryzysem wewnętrznym, nowe pytania i zmusił ją do dojrzalszego spojrzenia na więź Izraela z Bogiem, a tym samym na jego relację w stosunku do świata, a zwłaszcza dramatów dziejowych, które mogą dotknąć naród wybrany szczególnie dramatu zła moralnego i fizycznego. Ekonomia zbawienia, obejmująca kwestię stworzenia świata przez Boga, nadaje wierze Izraela nowe oparcie i uzasadnienie, sam zaś Izrael umacnia swoją ufność, doświadczając na gruncie tej wiary, że to sam Bóg jest podstawą wszelkiej rzeczywistości, a zło ma swoje źródło w człowieku, choć Stwórca uwzględnia je w ramach swojej pedagogii zbawczej, to znaczy w prowadzeniu człowieka do tego, by umiał znaleźć dla siebie właściwe miejsce w świecie i zająć stanowisko wobec pojawiających się wyzwań. Starotestamentalna teologia stworzenia ma więc na celu pouczenie człowieka o tym, że Bóg jest przed wszystkim i ponad

${ }^{14} \mathrm{~J}$. Ratzinger, Przekazywanie i źródła wiary, w: Powstanie i znaczenie Katechizmu Kościoła Katolickiego w wypowiedziach papieża Jana Pawła II $i$ kardynała Josepha Ratzingera, red. J. Królikowski, Poznań 1997, s. 83. 
wszystkim, w związku z czym od Niego trzeba wychodzić w spojrzeniu na każdą rzeczywistość i każdą sprawę, zwłaszcza na zło ${ }^{15}$.

Nowotestamentalna teologia stworzenia, pogłębiona chrystologicznie i pneumatologicznie, sytuuje się właściwie w tej samej perspektywie, choć zyskuje nowe argumenty. Kosmos i człowiek pochodzący od Boga, mający w Nim swój sens i swój cel, jest przestrzenią i uczestnikiem zbawczego działania Bożego. Człowiek, zanurzony w stworzeniu, jako jego kapłan, przyjmuje dar świętości Bożej i może ją rozwijać w ramach stworzenia, dokonując równocześnie jego konsekracji. Wiara biblijna podpowiada, że stworzenie jest integralnym elementem działania Boga na rzecz człowieka wierzącego, niezastąpionym dla przeżywania wiary i ukazania jej perspektyw egzystencjalnych.

Nie jest też bez znaczenia dla całości biblijnego rozumienia stworzenia fakt, iż w Biblii mamy do czynienia z wieloma teologiami stworzenia ${ }^{16}$.

Wydaje się również rzeczą ważną uwzględnienie tego, że biblijna teologia stworzenia narodziła się w kontekście kryzysu wiary, którego doświadczył Izrael. Można stwierdzić, że również w Kościele zachodzi zbieżność między kryzysami wiary i kryzysami teologii stworzenia. Nie będzie więc nadużyciem, jeśli sformułujemy w tym miejscu postulat, iż w kontekście przeżywanego dzisiaj kryzysu wiary, powinno się zwrócić większą uwagę na teologię stworzenia i należące do niego elementy teologiczne.

2. Z punktu widzenia teologicznego ważne byłoby ponowne przebadanie, czego właściwie naucza Kościół, gdy mówi o Bogu jako Stwórcy oraz o człowieku i świecie jako Bożych stworzeniach. Niejednokrotnie zauważa się, i to nie tylko w wypowiedziach nie-teologów, poważne nieporozumienia odnośnie do znajomości tej problematyki. Uważa się za wykładnię nauki Kościoła takie czy inne ujęcie teologiczne, które nie określa wiary z dogmatycznego punktu widzenia. Zwłaszcza w kontekście wspomnianego wyżej nowego ateizmu jest to niemal powszechne. $\mathrm{W}$ jego ramach krytykuje się pojęcia Boga Stwórcy i stworzenia, które nie mają nic wspólnego z nauczaniem Kościoła, a nawet z żadnym wykładem teologicznym. Sprawa jest stosunkowo prosta, ponieważ chodzi o teologiczne zbadanie, bardzo zresztą nielicznych, oficjalnych wypowiedzi Kościoła na ten temat.

Jak w każdym przypadku, tak i w kwestii doktryny o stworzeniu należy dostrzec jej ewidentny rozwój, zrozumiały przy uwzględnieniu kontekstu, w którym on się dokonał, a także zmieniającego się pod wpływem przemian kulturowych wewnętrznego rozkładu akcentów. Trzeba więc także w protologii powrócić do hermeneutyki wypowiedzi doktrynalnych, która jest ważna w ramach każdej kwestii teologicznej.

3. Biorąc pod uwagę biblijne opisy stworzenia jako punkt wyjścia, nigdy nie będzie dosyć refleksji teologicznej mającej za przedmiot człowieka ujmo-

\footnotetext{
${ }^{15}$ Por. J. Trublet, La creazione second l'Antico Testamento, „La Civiltà Cattolica” 3(2012), s. 147-146.

${ }^{16}$ Por. K. Löning, E. Zenger, Als Anfang schuf Gott. Biblische Schöpfungstheologien, Düsseldorf 1997.
} 
wanego w jego specyfice i wyjątkowości, łącznie z relacją mężczyzna - kobieta. Na pierwszym miejscu trzeba w ogóle dostrzec mającą już źródła biblijne wyjątkowość stworzenia człowieka, gdyż w dotychczasowych ujęciach stworzenie człowieka było traktowane na ogół jako dodatek do traktatu o stworzeniu. Poszczególnych zagadnień domagających się potem pogłębionego namysłu $\mathrm{w}$ tak postawionym zagadnieniu jest bardzo dużo. Wystarczy tutaj przypomnieć tradycyjną kwestię człowieka stworzonego „na obraz i podobieństwo Boże", mając także na względzie odzwierciedlanie się tego obrazu w ramach wzajemności mężczyzny i kobiety oraz w ramach relacji społecznych w ogólności. Konstytucja Gaudium et spes II Soboru Watykańskiego zwróciła uwagę na to zagadnienie, ale pozostaje ono ciągle mało zauważane ${ }^{17}$.

Należałoby w odniesieniu do tego zagadnienia pogłębić teologię ciała, płciowości jako elementu konstytutywnego tożsamości osobowej, relacyjności mężczyzny i kobiety, mając na względzie sens soteriologiczny tych rzeczywistości, dowartościowując ich wymiar symboliczny (ważny zarówno w odniesieniu do kwestii małżeństwa, jak i w odniesieniu do udzielania święceń tylko mężczyznom). Nie byłby pozbawiony znaczenia powrót do kwestii dowartościowania objawieniowego i soteriologicznego znaczenia materii i przyrody, relacji człowieka do tej sfery rzeczywistości w kontekście teologii pracy, wykorzystywania świata oraz pilnej dzisiaj kwestii ekologii, która może być adekwatnie ujęta tylko w perspektywie teologiczno-etycznej. Gdy w tej ostatniej dziedzinie brakuje teologii, tam pojawia się ideologia ${ }^{18}$. Są to kwestie ściśle związane $\mathrm{z}$ humanizmem biblijnym, który ciągle ma wiele do zaproponowania człowiekowi szukającemu stylu życia na miarę jego samego ${ }^{19}$.

Wydaje się, że - po odpowiednim oczyszczeniu - byłaby bardzo użyteczna dla teologii propozycja Martina Heideggera, by widzieć człowieka jako „pasterza bytu”, która mogłaby posłużyć do dowartościowania metafizyki w spojrzeniu na człowieka i jego relację ze światem.

4. Nauka o stworzeniu ma bogate reperkusje w dziedzinie etyki. Tylko przy założeniu, że świat pochodzi od Boga, a nie jest wynikiem procesów wewnętrznej transformacji chaosu, można uzasadnić istnienie uniwersalnych norm moralnych. $\mathrm{Z}$ teologii stworzenia wyrasta doktryna naturalnego prawa moralnego. Dzisiejszy kryzys w rozumieniu tego rodzaju prawa jest wyraźnie związany z kryzysem teologii stworzenia.

5. Mając świadomość złożoności zagadnienia, nie należy rezygnować z wychodzącego od teologii stworzenia spojrzenia na ludzką racjonalność i wolność, które w tym kontekście zyskują znaczące uzasadnienie, pogłębienie i wsparcie. Pochodzenie człowieka od Boga jest ostateczną gwarancją jego

${ }^{17}$ Por. J. Ratzinger, Kommmentar zu Art. 11-22 der Pastoralkonstitution Gaudium et spes, w: Lexikon für Theologie und Kirche, Ergänzungsband III, Freiburg - Basel - Wien 1968, s. 313-355.

${ }^{18}$ Por. J. Królikowski, „Na początku Bóg stworzyt...”. Konsekwencje wiary w Boga Stwórce, w: Odpowiedzialność za życie i stworzony świat, red. A. Żurek, Tarnów 2011, s. 9-22.

${ }^{19}$ Por. C. Di Sante, L'uomo alla presenza di Dio. L'umanesimo biblico, Brescia 2010. 
racjonalności i wolności oraz - co się z tym wiąże - także źródłem sensu, którego poszukuje. Zakorzenienie człowieka w wiecznym Rozumie i w wiecznej Wolności ukazuje człowiekowi jego wielkość i sensowność, pozwalając mu zająć właściwe miejsce w świecie i przeżywać swoją historyczność.

W takim ujęciu teologia stworzenia jawi się jako jeden z kluczowych problemów rozpatrywanych $w$ ramach relacji rozumu i wiary, gdyż pozwala na wypracowanie wspólnego punktu wyjścia obu ludzkich działań, otwierających je potem na dialog i współpracę. Analiza przemian zachodzących w ciągu wieków w rozumieniu racjonalności pokazuje, że były one wyraźnie uzależnione od sposobu ujmowania problematyki dotyczącej stworzenia.

6. Jedno z kluczowych przekonań, które usiłuje się wcisnąć w dzisiejszą mentalność, dotyczy nienaukowości doktryny stworzenia ex nihilo. Analizując współczesne wypowiedzi na temat początku świata, wobec faktu rozmywania systematycznego charakteru tej problematyki, F. Foulatier wyprowadził następujący wniosek: „Można także założyć, że jedną z funkcji dyskursu naukowego stosowanego do zagadnień początku jest zdyskwalifikowanie idei stworzenia"20.

Takie stawianie sprawy stworzenia domaga się przynajmniej dwóch rzeczy. Po pierwsze, trzeba zająć się problematyką stworzenia w ramach filozofii, co może dostarczyć racji przemawiających za racjonalnością tego zagadnienia, a tym samym za jego naukowym charakterem. Refleksja filozoficzna może również wydatnie przyczynić się do krytyki ewolucji pojmowanej jako filozofia, gdy tymczasem jest ona teorią naukową wyjaśniającą pewne zjawiska zachodzące w świecie, ale nie rozwiązującą problemu pochodzenia świata. Po drugie, trzeba kontynuować dialog z naukami przyrodniczymi, by przekazywać jasny pogląd na temat tego, czym są teorie filozoficzno-teologiczne, a czym są dane dostarczane przez te nauki. Ciągłe napięcia między nauką i wiarą są powodowane brakami dotyczącymi znajomości drugiej strony a zwłaszcza nierozróżnianiem ich kompetencji, które może być zapewnione tylko na gruncie odpowiednich rozróżnień metodologicznych dotyczących obu tych dziedzin ludzkiego doświadczenia i poznania ${ }^{21}$. Niestety, braki w znajomości teologii u przedstawicieli nauk przyrodniczych są bardzo wyraźnie widoczne; sprawiają one, że można często spotkać w ich wypowiedziach wręcz ekstrawaganckie stwierdzenia i oceny dotyczące wiary i teologii.

Teologia w swoim spojrzeniu na stworzenie, w ramach swojej wrażliwości metodologicznej, musi w ujmowaniu tego zagadnienia zachować perspektywę tajemnicy, by nie zredukować swoich poszukiwań tylko do punktu widzenia racjonalistycznego, co zagraża rozpatrywaniu tej problematyki w kontekście nauk przyrodniczych. Warto więc przytoczyć wskazówkę sformułowaną przez Matthiasa Josepha Scheebena w Tajemnicach chrześcijaństwa: „Prawdziwa [...] i właściwa tajemnica świata stworzonego według pojęć chrześcijańskich musi być czymś tak wzniosłym, że opierając się na przesłan-

\footnotetext{
${ }^{20}$ F. Foultier, Le roman cosmogonique, Paris 1988, s. 16.

${ }^{21}$ Por. E. Boncinelli, G. Coyne, Bóg, wszechświat i sens życia. Ateista i wierzacy - konfrontacja dwóch ludzi, tłum. B. Bochenek, Kraków 2010.
} 
kach czysto rozumowych, nie jesteśmy w stanie jej poznać nawet niedoskonale. Jest zaś zakryta i tajemnicza nie tyle dlatego, że stanowi coś tak bardzo głębokiego i trudnego do poznania jak sama istota i rdzeń rzeczy stworzonych, ile raczej, że znajduje się nieskończenie wysoko ponad najbardziej wewnętrzną istotą stworzeń tak dalece, że gdybyśmy nawet tę ostatnią doskonale poznali, nie uczynilibyśmy jeszcze ani jednego kroku naprzód w celu odsłonięcia tajemnicy, jaką Bóg włożył w stworzenie",22.

${ }^{22}$ M.J. Scheeben, Tajemnice chrześcijaństwa, tłum. J. Roztworowski, I. Bieda, Kraków 1970, s. 164. 